\title{
Thermogravimetric Analyses and Mineralogical Study of Polymer Modified Mortar with Silica Fume
}

\author{
Alessandra Etuko Feuzicana de Souza Almeida*, Eduvaldo Paulo Sichieri \\ School of Engineering of São Carlos, University of São Paulo, \\ Av. Trabalhador São Carlense, 400, 13566-590 São Carlos - SP, Brazil
}

Received: March 3, 2006; Revised: June 26, 2006

\begin{abstract}
Mineral and organic additions are often used in mortars to improve their properties. Microstructural investigation concerning the effects of styrene acrylic polymer and silica fume on the mineralogical composition of high-early-strength portland cement pastes after 28 days of hydration are presented in this paper. Thermogravimetry and derivative thermogravimetry were used to study the interaction between polymers and cement, as well as the extent of pozzolanic reaction of the mortars with silica fume. Differential scanning calorimetry and X ray diffraction were used to investigate the cement hydration and the effect of the additions. The results showed that the addition of silica fume and polymer reduces the portlandite formation due to delaying of Portland cement hydration and pozzolanic reaction.
\end{abstract}

Keywords: silica fume, polymer, thermal analysis, $X$ ray diffraction

\section{Introduction}

Nowadays polymer modification of cementitious materials is frequently used in specific situations, where high performance towards durability, adhesion with substrates, or waterproofing properties is required. Pozzolanic materials can partially substitute Portland cement in order to enhance the properties of concrete and mortars such as durability and mechanical properties.

Polymer modified mortars are known as a popular construction material because of their excellent performance. The fundamentals about polymer modification for cement mortar and concrete have been studied for the past 80 years or more. Cement mortar and concrete made by adding polymer-based admixtures are called polymer-modified mortar (PMM) and polymer-modified concrete (PMC), respectively ${ }^{1,2}$.

Polymeric admixture, or cement modifier, is defined as an admixture which consists of a polymeric compound that acts as a main ingredient in modifying or improving properties such as strength, deformation, adhesion, waterproofing and durability of mortars and concretes. Polymer latex is a colloidal dispersion of small polymer particles in water, which is obtained by emulsion polymerization of monomers with emulsifiers ${ }^{3,4}$.

The literature agrees that the properties of polymer-modified mortar and concrete depend significantly on the polymer content or polymer-cement ratio, that is, the mass ratio of the amount of polymer solids in a polymer-based admixture to the amount of cement in a polymer-modified mortar or concrete ${ }^{1,2,5}$.

There are two proposed theories of action for polymer in concrete $^{6,7}$. According to the first theory, there is no interaction between the polymer and cement, therefore during hydration the hydrophilic part of the polymer is oriented towards the water phase whereas the hydrophobic part head towards the air phase. The water is dried out in the setting phase, the polymer particles coalesce and build up a monolithic matrix phase with a network structure in which the hydrated cement phase and polymer phase interpenetrate into each other. The second theory is that the polymer interacts with the Portland cement hydration products and forms complexes.

The action of the saturated $\mathrm{Ca}(\mathrm{OH})_{2}$, solution on the surface of the set styrene-acrylate dispersion was studied ${ }^{6,8,9}$. On the other hand, the behavior of individual Portland cement components with polymers was found to be different when they are present together in cement. However, the mechanism of the interaction considering all the components of Portland cement acting simultaneously and polymers is not clear yet and discrepancies still exist ${ }^{6}$.

Silica fume or microsilica is an industrial by-product from an electric arc furnace producing silicon and ferrosilicon alloys. It has been widely used as a concrete and mortar mixture, mainly to improve the mechanical properties and reduce porosity, due to pozzolanic activity ${ }^{10,11}$.

Finely ground material such as silica fume can increase the water required for a given degree of workability at low water-cement ratio, thus water reducing admixture (or superplasticizer) is often used to improve the workability of mortars with silica fume ${ }^{10}$.

Taking this into account, the correct combination of silica fume, superplasticizer and polymeric additions may have the synergistic effects of these three admixtures, resulting in the construction material performing well in specific applications, for example, high quality repairing and overlaying materials when applying concrete structures $^{12-14}$.

In previous work, the authors studied the effects of silica fume and acrylic polymer on mortar properties, specifically to install porcelain tiles ${ }^{14}$. The mentioned work showed the improvement of adherence strength of mortars using such additions. Therefore, the aim of this work is to investigate the influence of such admixtures concerning the hydration of Portland cement by means of the mineralogical study of pastes with the same composition used in the work ${ }^{14}$.

The interaction between additions and cement portland can be investigated by various techniques such as thermal analysis and $X$ ray diffraction. Thermogravimetry (TG), derivative thermogravimetry (DTG) and differential scanning calorimetry (DSC) are considered important tools to evaluate the nature of hydrated products according to different stages of cement hydration, in addition to quantifying the different phases ${ }^{15-18}$.

When cement is hydrated, its main components are transformed into hydration products, mainly calcium silicate hydrate $(\mathrm{C}-\mathrm{S}-\mathrm{H})$ and 
portlandite. The hydration can be evaluated by measuring the mass loss of hydrated compounds up to $900{ }^{\circ} \mathrm{C}$. The following peaks and temperature ranges have been studied when hydrated cement is heated in thermobalance ${ }^{16,17}$.

This study reports the results of investigations in which methods of thermal analysis, TG, DTG and DSC were applied to investigate the effects of polymer modification on the process of hydration of Portland cement by estimating $\mathrm{Ca}(\mathrm{OH})_{2}$ content and C-S-H content. $\mathrm{X}$ ray diffraction was carried out to study the hydrate products of cement ${ }^{19}$

\section{Materials}

\subsection{Cement and silica fume}

The mortars were prepared using high-early-strength Portland cement (CPV-ARI Plus) according to NBR 5733; and Type III cement according to ASTM C150). Chemical and physical properties of cement are shown in Tables 1 and 2, respectively, according to the manufacturer. The silica fume used was provided by Microssilica Brazil, with a specific surface area of $27.74 \mathrm{~m}^{2} / \mathrm{g}$ obtained by the BET test, and $94.3 \% \mathrm{SiO}_{2}$ content. Table 3 shows the chemical properties of silica fume, according to the manufacturer.

\subsection{Superplasticizer}

The superplasticizer, provided by MBT Brazil I. C., was used presenting chemical base sulfonated melamine, liquid aspect, density $1.11 \mathrm{~g} / \mathrm{cm}^{3}( \pm 0.02)$, pH: $8.5 \pm 16.49 \%$ solids content.

\subsection{Polymer latex}

- Aqueous dispersion of styrene-acrylate copolymer with $49 \%$ to $51 \%$ total solid content; Viscosity Brookfield (RVT $415{ }^{\circ} \mathrm{C}$ ): 1000-2000 mPas; Density: $1.02 \mathrm{~g} / \mathrm{cm}^{3}$; $\mathrm{pH}$ value: 4.5 a 6.5 ;

- Minimum film-forming temperature: $20^{\circ} \mathrm{C}$;

- Mean size of particles: $0.1 \mu \mathrm{m}$;

- Film properties: Clear and transparent; and

- Stability to ageing: good.

\section{Experimental Program}

Six mixtures were prepared as described in Table 4, which are the pastes with the same proportions used in the previous work ${ }^{14}$. The materials were weighed and mixed in a planetary-type mortar mixer. The total quantity of water was maintained, taking into account the water from the latex. The superplasticizer was also added in the ratio of $1 \%$ of the weight of cement.

The preparation of the samples for TG, DSC and X ray diffraction was carried out using an agate mortar and pestle, in which the paste was manually ground until the size of particles was lower than $0.063 \mathrm{~mm}$. To prevent carbonation and maintenance of relative humidity, all specimens were stored in the vacuum up to the time of when the test started.

The analyses were performed at the Institute of Chemistry of São Carlos, University of São Paulo, using TGA 2050 Thermogravimetric Analyzer V5.1A equipment. The experimental conditions were: $\mathrm{N}_{2}$ gas dynamic atmosphere $\left(40 \mathrm{ml} \cdot \mathrm{min}^{-1}\right)$; heating rate $\left(10^{\circ} \mathrm{C} \cdot \mathrm{min}^{-1}\right)$ and a platinum top-opened crucible. The samples were heated in the range of 20 to $900{ }^{\circ} \mathrm{C}$ at a constant rate. The $\mathrm{Ca}(\mathrm{OH})_{2}$ was estimated from the weight loss measured in the TG curve between the initial and final temperature of the corresponding DTG peak.

Differential scanning calorimetry (DSC) was used to investigate the combined effect of silica fume and polymer on heat development in the pastes. A DSC 2010 Differential Scanning Calorimeter was
Table 1. The chemical composition of cement.

\begin{tabular}{lc}
\hline Chemical composition & CPV-ARI-Plus $(\%)$ \\
\hline $\mathrm{Loss}_{\text {on }}$ ignition & 3.10 \\
$\mathrm{SiO}_{2}$ & 18.99 \\
$\mathrm{Al}_{2} \mathrm{O}_{3}$ & 4.32 \\
$\mathrm{Fe}_{2} \mathrm{O}_{3}$ & 3.00 \\
$\mathrm{CaO}$ total & 64.7 \\
$\mathrm{MgO}$ & 0.68 \\
$\mathrm{SO}_{3}$ & 3.01 \\
$\mathrm{Na}_{2} \mathrm{O}$ & 0.03 \\
$\mathrm{~K}_{2} \mathrm{O}:$ & 0.85 \\
$\mathrm{CO}_{2}:$ & 1.81 \\
$\mathrm{RI}_{\mathrm{CaO}}$ & 0.26 \\
\hline
\end{tabular}

Table 2. Physical properties of cement.

\begin{tabular}{ccccccc}
\hline $\begin{array}{c}\text { Setting time } \\
(\mathrm{min})\end{array}$ & $\begin{array}{c}\text { Blaine } \\
\text { surface }\end{array}$ & \multicolumn{4}{c}{ Compressive strength (MPa) } \\
NBR 7215
\end{tabular}

Table 3. The chemical compositions of silica fume.

\begin{tabular}{cc}
\hline Chemical composition & $\%$ \\
\hline $\mathrm{SiO}_{2}$ & 94.3 \\
$\mathrm{Al}_{2} \mathrm{O}_{3}$ & 0.09 \\
$\mathrm{Fe}_{2} \mathrm{O}_{3}$ & 0.10 \\
$\mathrm{CaO}$ & 0.30 \\
$\mathrm{MgO}$ & 0.43 \\
$\mathrm{SO}_{3}$ & - \\
$\mathrm{K}_{2} \mathrm{O}$ & 0.83 \\
$\mathrm{Na}_{2} \mathrm{O}$ & 0.27 \\
\hline
\end{tabular}

used. The experimental conditions were: $\mathrm{N}_{2}$ gas dynamic atmosphere $\left(40 \mathrm{ml} \cdot \mathrm{min}^{-1}\right)$; heating rate $\left(10{ }^{\circ} \mathrm{C} \cdot \mathrm{min}^{-1}\right)$ and platinum top-opened crucible. The samples were heated in the range of $25^{\circ} \mathrm{C}$ to $500{ }^{\circ} \mathrm{C}$ at a constant rate.

XRD was used to identify the polycrystalline phases of cement and hardened cement paste. The qualitative XRD investigation was performed in a Carl Zeiss-Jena Universal Diffractometer, URD6 model at the Institute of Chemistry of São Carlos, University of São Paulo.

\section{Results and Discussion}

Table 4 shows the mixture proportions investigated. Figures 1 and 2 show the TG curves of pastes with silica fume content of $5 \%$ and $10 \%$ respectively (P5 and P6). It can be seen that TG curves for these pastes consist of four zones:

- 25-123. ${ }^{\circ} \mathrm{C}$ : dehydration of pore water;

- 123.3-420 ${ }^{\circ} \mathrm{C}$ : dehydration of calcium silicate hydrates;

- 420-480 ${ }^{\circ} \mathrm{C}$ : dehydroxylation of calcium hydroxide; and

- 480-730 ${ }^{\circ} \mathrm{C}$ : decarbonation of $\mathrm{CaCO}_{3}$.

Figures 3 and 4 show the TG curves of pastes with $5 \%$ silica fume and polymer addition of $5.2 \%$ and $10.4 \%$ (polymeric solids), respectively. Figures 5 and 6 present TG curves of pastes with $10 \%$ 
Table 4. Mixture proportion of the mortars.

\begin{tabular}{ccccc}
\hline $\begin{array}{c}\text { Designation of paste } \\
\text { P1 }\end{array}$ & $\begin{array}{c}\text { Silica fume content } \\
(\%)^{*}\end{array}$ & $\begin{array}{c}\text { Polymer Latex content } \\
(\%)^{*}\end{array}$ & $\begin{array}{c}\text { Solids of polymer content } \\
(\%)^{*}\end{array}$ & Water/cement ratio \\
P2 & 5 & 10 & 5.2 & 0.36 \\
P3 & 5 & 20 & 10.4 & 0.31 \\
P4 & 10 & 10 & 5.2 & 0.36 \\
P5 & 10 & 20 & 0 & 0.31 \\
P6 & 5 & 0 & 0 & 0.36 \\
\hline
\end{tabular}

*by weight of cement.

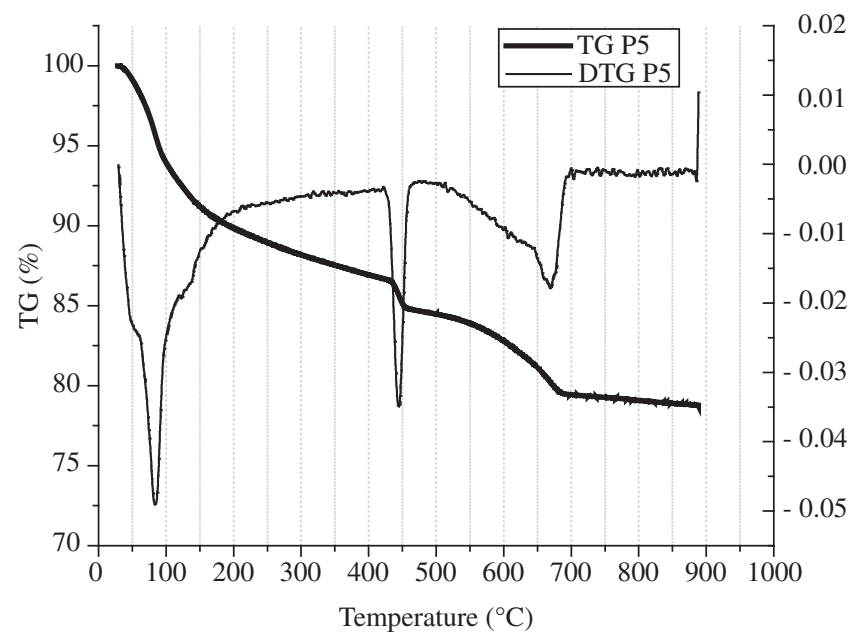

Figure 1. TG curve of the paste without polymer and 5\% of silica fume P5.

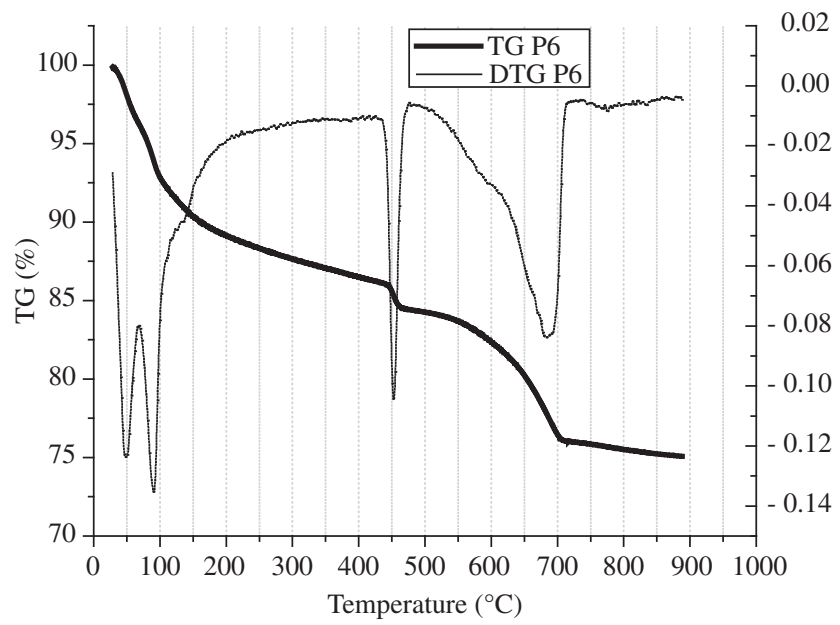

Figure 2. TG curve of the paste without polymer and $10 \%$ of silica fume P6.

silica fume and polymer addition of 5.2\% and 10.4\% (polymeric solids), respectively. The TG curves obtained in these tests are typical of hydrated cement pastes containing carbonate phases and polymeric admixtures. The curves can be divided into five major parts, according to different reactions:

- 25-123. ${ }^{\circ} \mathrm{C}$ : dehydration of pore water;

- 123.3-345 ${ }^{\circ} \mathrm{C}$ : dehydration of calcium silicate hydrates;

- 345-427 ${ }^{\circ} \mathrm{C}$ : weight loss due to polymer pyrolysis and dehydration of part of silicate hydrates;

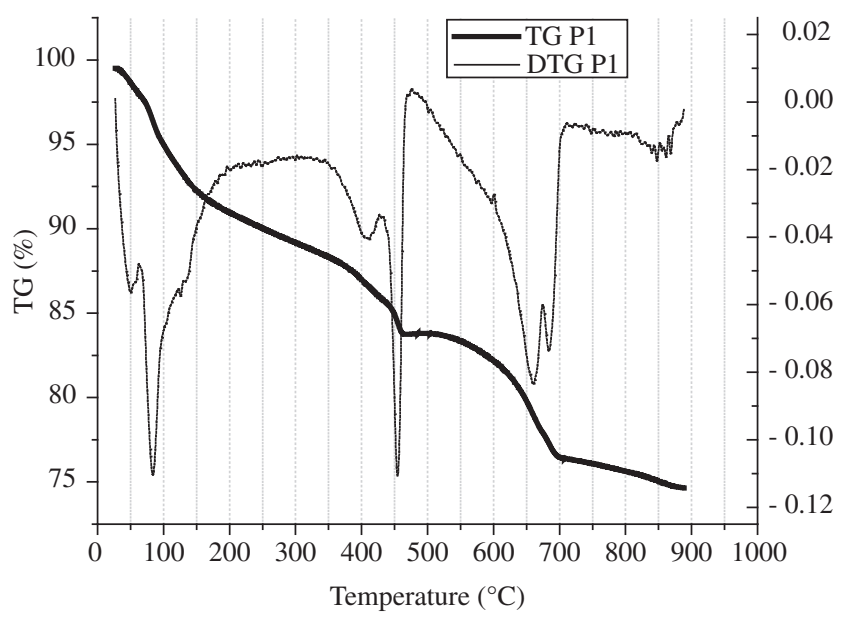

Figure 3. TG curve of the paste P1.

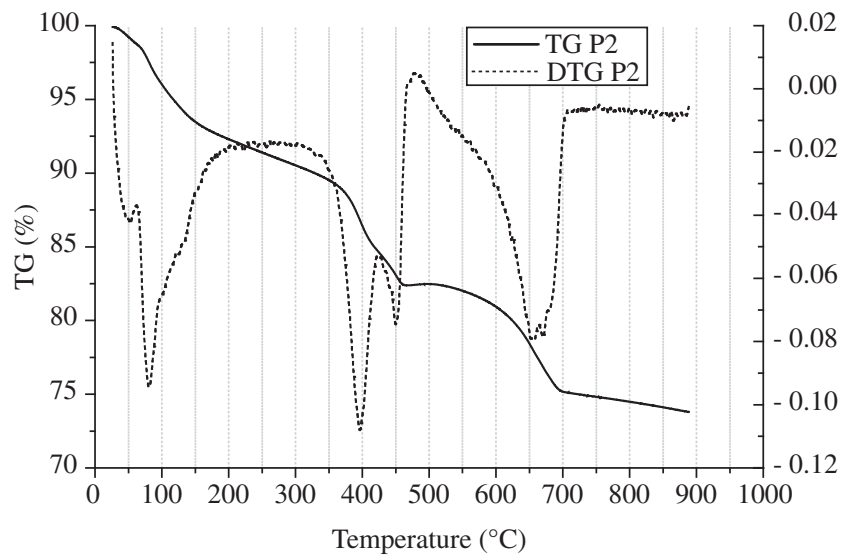

Figure 4. TG curve of the paste P2.

- 427-475 ${ }^{\circ} \mathrm{C}$ : dehydroxylation of calcium hydroxide; and - 475-711 ${ }^{\circ} \mathrm{C}$ : decarbonation of $\mathrm{CaCO}_{3}$.

The weight loss for each temperature range can be seen in Table 5 . Regarding pastes with polymer addition, the weight loss related to the dehydroxylation of calcium hydroxide is lower than pastes with silica fume addition alone.

Figure 7 shows the DSC curves obtained for the pastes studied. From these results it is clear that pastes with polymer present different results from the pastes which do not contain polymer. All curves 


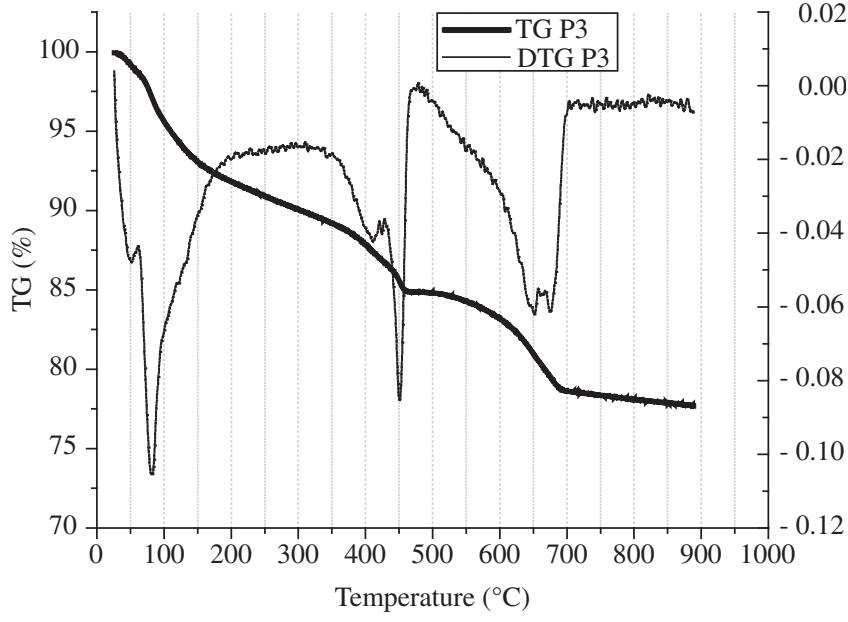

Figure 5. TG curve of the paste P3.

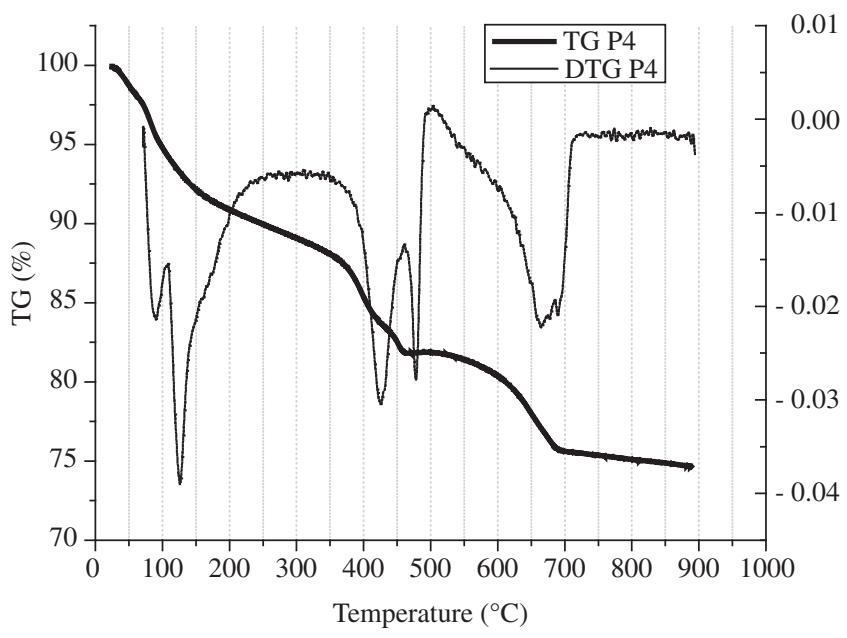

Figure 6. TG curve of the paste $\mathrm{P} 4$.

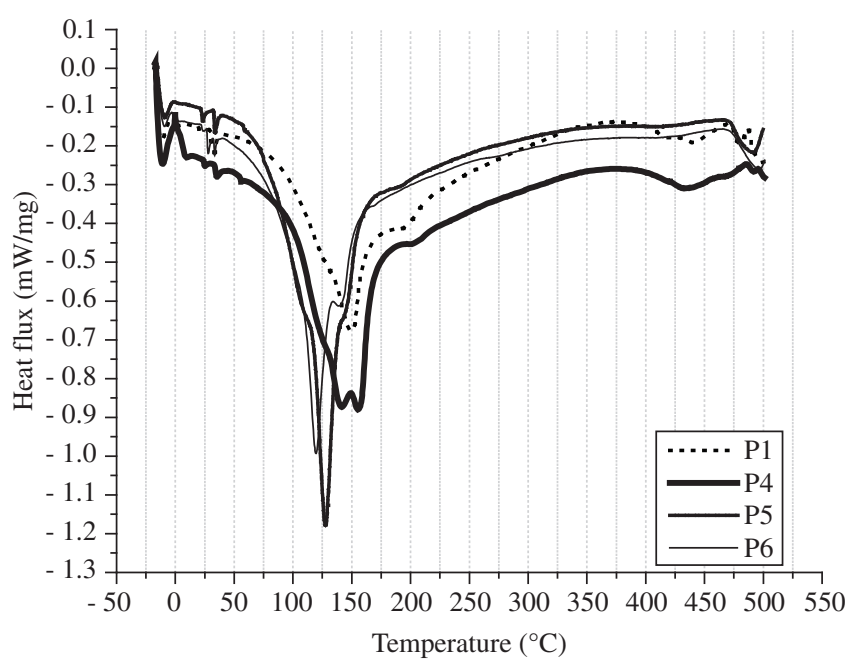

Figure 7. DSC curves of the pastes P1, P4, P5 and P6.
Table 5. Weight loss of the pastes according to the temperature.

\begin{tabular}{|c|c|c|}
\hline & Temperature range $\left({ }^{\circ} \mathrm{C}\right)$ & Weight loss (\%) \\
\hline \multirow[t]{5}{*}{$\mathrm{P} 5$} & 28.3 a 123.3 & 7.487 \\
\hline & 123.3 a 416.2 & 5.75 \\
\hline & 416.7 a 472.1 & 2.056 \\
\hline & 472.1 a 702.3 & 5.258 \\
\hline & Residue above $850^{\circ} \mathrm{C}$ & 78.9 \\
\hline \multirow[t]{5}{*}{ P6 } & 25.2 a 123.3 & 8.43 \\
\hline & 123.3 a 420.6 & 5.238 \\
\hline & 420.6 a 478.8 & 1.876 \\
\hline & 478.8 a 729.2 & 8.436 \\
\hline & Residue above $850^{\circ} \mathrm{C}$ & 75.23 \\
\hline \multirow[t]{6}{*}{ P1 } & 25.9 a 123.3 & 5.922 \\
\hline & 123.3 a 337.9 & 5.037 \\
\hline & 337.9 a 429.6 & 2.665 \\
\hline & 429.6 a 481 & 2.095 \\
\hline & 481 a 711.3 & 7.412 \\
\hline & Residue above $850^{\circ} \mathrm{C}$ & 75.04 \\
\hline \multirow[t]{6}{*}{$\mathrm{P} 2$} & 26.1 a 123.3 & 5.236 \\
\hline & 123.3 a 333.4 & 4.767 \\
\hline & 333.4 a 422.9 & 5.175 \\
\hline & 422.9 a 478.8 & 2.301 \\
\hline & 478.8 a 713.5 & 7.357 \\
\hline & Residue above $850^{\circ} \mathrm{C}$ & 74.12 \\
\hline \multirow[t]{6}{*}{ P3 } & 25.2 a 123.3 & 5.695 \\
\hline & 123.3 a 344.6 & 4.949 \\
\hline & 344.6 a 427.3 & 2.53 \\
\hline & 427.3 a 474.3 & 1.912 \\
\hline & 474.3 a 711.3 & 6.308 \\
\hline & Residue above $850^{\circ} \mathrm{C}$ & 77.89 \\
\hline \multirow[t]{6}{*}{$\mathrm{P} 4$} & 24.6 a 123.3 & 6.544 \\
\hline & 123.3 a 344.6 & 5.175 \\
\hline & 344.6 a 429.6 & 4.663 \\
\hline & 429.6 a 476.5 & 1.707 \\
\hline & 476.5 a 713.5 & 6.289 \\
\hline & Residue above $850^{\circ} \mathrm{C}$ & 74.88 \\
\hline
\end{tabular}

show an endothermic peak around $480{ }^{\circ} \mathrm{C}$, but they are more intense for pastes with silica fume alone because of the higher $\mathrm{Ca}(\mathrm{OH})_{2}$ content. Pastes with silica fume and polymer present an exothermic peak around $350{ }^{\circ} \mathrm{C}$, indicating polymer pyrolysis, as was found from the TG/DTG analyses. The pastes modified with polymer presented higher heat absorption between $100{ }^{\circ} \mathrm{C}$ and $200{ }^{\circ} \mathrm{C}$, suggesting that these pastes contain more free water resulting from the hydration being delayed, and that these have a higher amount of calcium silicate hydrates.

The XRD results show some qualitative differences in the hydration rate due to the incorporation of silica and polymer. Figures 8,9 and 10 show the $\mathrm{X}$ ray patterns of the pastes with $5 \%, 10 \%$ of silica fume, and pastes with polymer. The main compounds observed are $\mathrm{Ca}(\mathrm{OH})_{2}$ in the form of portlandite, a small amount of $\mathrm{CaCO}_{3}$ resulting from carbonation of $\mathrm{Ca}(\mathrm{OH})_{2}$, which occurred during hydration and anhydrous calcium silicate. The peak intensity in the region of $2 \theta=18^{\circ}$ has been considered as a measurement of the intensity of $\mathrm{Ca}(\mathrm{OH})_{2}$ for the comparison between the samples ${ }^{19}$. Therefore, 


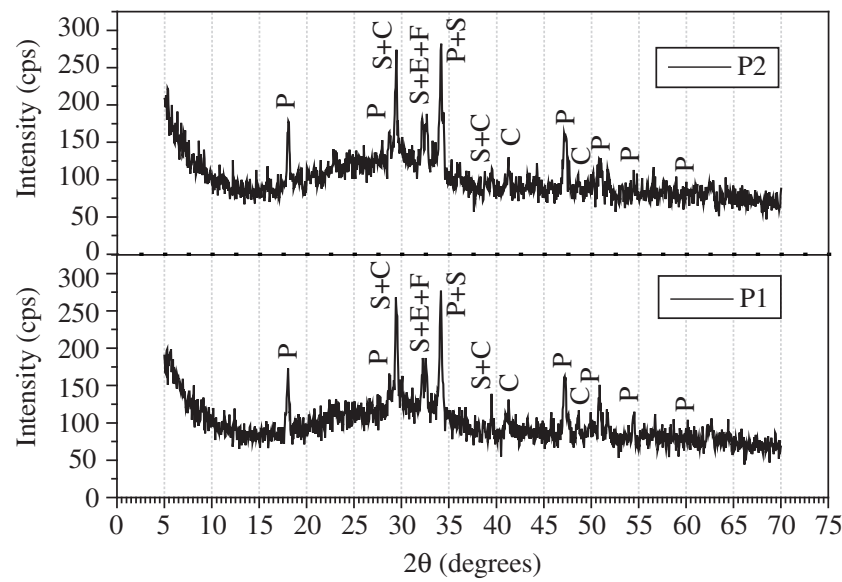

Figure 8. XRD patterns of the $\mathrm{P} 1$ and $\mathrm{P} 2$ pastes after 28 days of hydration. P. portlandite $\left(\mathrm{Ca}(\mathrm{OH})_{2}\right)$; CC. Calcium carbonate $\left(\mathrm{CaCO}_{3}\right)$; E. ettringite $\left(\mathrm{Ca}_{6}\left[\mathrm{Al}(\mathrm{OH})_{6}\right]_{2}\left(\mathrm{SO}_{4}\right)_{3} \cdot 26 \mathrm{H}_{2} \mathrm{O}\right) ; \mathrm{S}$. silicates; F. ferrite.

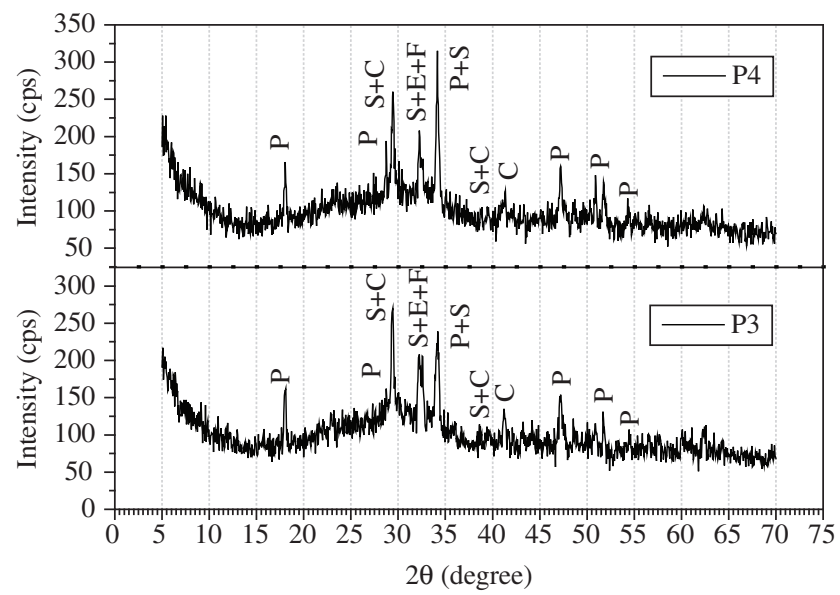

Figure 9. XRD patterns of the $\mathrm{P} 3$ and $\mathrm{P} 4$ pastes after 28 days of hydration. P. portlandite $\left(\mathrm{Ca}(\mathrm{OH})_{2}\right)$; CC. Calcium carbonate $\left(\mathrm{CaCO}_{3}\right)$; E. ettringite $\left(\mathrm{Ca}_{6}\left[\mathrm{Al}(\mathrm{OH})_{6}\right]_{2}\left(\mathrm{SO}_{4}\right)_{3} \cdot 26 \mathrm{H}_{2} \mathrm{O}\right) ; \mathrm{S}$. silicates; F. ferrite.

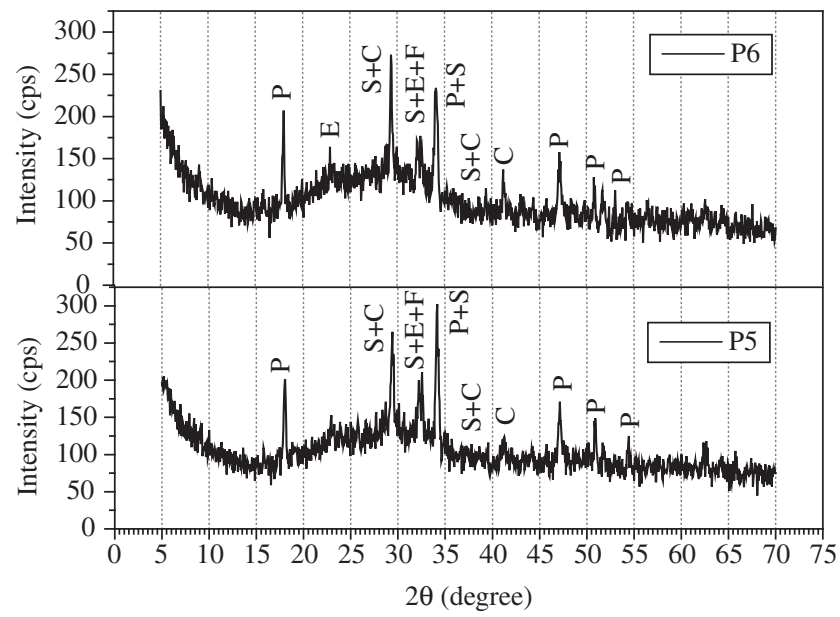

Figure 10. XRD patterns of the $\mathrm{P} 5$ and $\mathrm{P} 6$ pastes after 28 days of hydration. P. portlandite $\left(\mathrm{Ca}(\mathrm{OH})_{2}\right)$; CC. Calcium carbonate $\left(\mathrm{CaCO}_{3}\right)$; E. ettringite $\left(\mathrm{Ca}_{6}\left[\mathrm{Al}(\mathrm{OH})_{6}\right]_{2}\left(\mathrm{SO}_{4}\right)_{3} .26 \mathrm{H}_{2} \mathrm{O}\right) ;$ S. silicates; F. ferrite.
Figures 8, 9 and 10 show that $10 \%$ of silica fume replacement and polymer addition resulted in the lowest peak intensity for the portlandite $\left(\mathrm{Ca}(\mathrm{OH})_{2}\right)$.

\section{Conclusions}

The qualitative $\mathrm{XRD}$ investigation revealed that a lower intensity of $\mathrm{Ca}(\mathrm{OH})_{2}$ (in the region of $2 \theta=18^{\circ}$ ) was obtained in the presence of latex, compared to pastes without polymer. Similarly, we found a decrease in the $\mathrm{Ca}(\mathrm{OH})_{2}$ content in the TG analyses for pastes with polymer addition. As can be seen, pastes with polymer and $10 \%$ silica fume content presented the lowest $\mathrm{Ca}(\mathrm{OH})_{2}$ compared to the other pastes. From the thermogravimetric investigations performed, shown in the TG and DSC curves, it can be concluded that mineral admixtures and polymeric additions have influenced cement hydration, mainly when added simultaneously.

It can be concluded from the data reported in this paper and within the limits of the experimental conditions adopted that the additions studied resulted in the decrease of the portlandite content. Both the pozzolanic reaction, that transforms the weak calcium hydroxide crystals into the strong calcium silicate hydrate gel, and the delay of hydration due to polymer addition appear to cause a decrease in the portlandite content, contributing to the improvement of the mortars performance studied earlier by the authors.

\section{Acknowledgments}

The authors gratefully acknowledge the financial support from Fundação de Amparo a Pesquisa do Estado de São Paulo (FAPESP).

\section{References}

1. Ohama Y. Polymer based admixtures. Cement and Concrete Composites 1998; 20:189-220.

2. Fowler DW. Polymers in concrete: a vision for the $21^{\text {st }}$ century. Cement and Concrete Composite. 1999; 21:449-452.

3. Walters DG. What are latexes? Concrete International. 1987; 9(12):44 47.

4. Lavelle JA. Acrylic latex-modified Portland cement. ACI Materials Journal. 1998; 85(1):41-48.

5. Ohama Y. Recent progress in concrete-polymer composites. Advanced Cement Based Materials. 1997; 5:31-40.

6. Chandra S, Flodin P. Interactions of polymers and organic admixtures on Portland cement hydration. Cement and Concrete Research. 1987; 17:875-890.

7. Ohama Y. Principle of latex modification and some typical properties of latex modified mortar and concretes. American Concrete Institute - Materials Journal. 1987. p. 511-518.

8. Larbi JA, Bijen JM. Interaction of polymers with Portland cement during hydration: A study of the chemistry of the pore solution of polymer-modified cement systems. Cement and Concrete Research. 1990; 20:139-147.

9. Janotka I, Mandejova J, Stevula L, Frt'Alova DM. Behavior of $\mathrm{Ca}(\mathrm{OH})_{2}$ in the presence of the set styrene-acrylate dispersion. Cement and Concrete Research. 1996; 26(11):1727-1735.

10. Aïtcin Pierre-Claude. Concreto de Alto Desempenho. São Paulo: Ed. Pini; 2000 .

11. Male P. Properties of microssilica. Concrete. 1989; 23(8):31-34

12. Chakraborty AK, Dutta SC, Sen P, Ray I. Improved performance of silica fume modified mortar due to addition of polymer emulsions. Journal of Polymer Materials. 2000; 17(1):53-62.

13. Gao JM, Qian CX, Wang B, Morino K. Experimental study on properties of polymer-modified cement mortars with silica fume. Cement and Concrete Research. 2002; 32:41-45. 
14. Almeida AEF de S, Sichieri EP. Study of the adherence between polymer-modified mortars and porcelain stoneware tiles. Materials Research. 2005; 8(3):245-249.

15. Dweck J, Buchler P, Coelho A, Cartledge F. Hydration of a Portland cement blended with calcium carbonate. Thermochimica Acta. 2000; 346:105-113.

16. Fordham CJ, Smalley IJ. A simple thermogravimetric study of hydrated cement. Cement and Concrete Research. 1985; 15:141-144.
17. Tisivilis S, Kakali G, Chaniotakis E, Souravidou A. A study on the hydration of Portland limestone cement by means of TG. Journal of Thermal Analysis. 1998; 52:863-870.

18. Vedalakshmi R, Raj A, Srinivasan S, Babu K. Quantification of hydrated cement products of blended cements in low and medium strength concrete using TG and DTA technique. Thermochimica Acta. 2003; 407:49-60.

19. Afridi MUK, Ohama Y, Iqbal MZ, Demura K. Behavior of $\mathrm{Ca}(\mathrm{OH})_{2}$ in polymer-modified mortars. The International Journal of Cement Composites and Lightweight Concrete. 1989; 11(4):235-244. 